\title{
Analysis of p16 expression and allelic imbalance / loss of heterozygosity of 9p21 in cutaneous squamous cell carcinomas
}

\author{
Sarah E. Gray a, Elaine Kay a, Mary Leader a, M. Mabruk a, b, * \\ a Molecular Oncology Laboratory, Pathology Department, Royal College of Surgeons in Ireland and \\ Beaumont Hospital, Dublin, Ireland \\ ${ }^{b}$ Advanced Medical and Dental Institute, University Sains Malaysia, Penang, Malaysia
}

Received: March 6, 2006; Accepted: June 14, 2006

\begin{abstract}
Deletions of the short arm of chromosome 9 have been reported in different types of malignancies. This chromosomal region contains a number of known tumour suppressor genes, including the p16 $6^{\mathrm{INK} 4 \mathrm{~A}}$ (CDKN2A), p15 $5^{\mathrm{INK} 4 \mathrm{~B}}$ and MTAP tumour suppressor genes located at 9p21. In this study twenty-two paraffin embedded invasive cutaneous SCC were examined for allelic imbalance/ loss of heterozygosity (AI/LOH) of the 9p region (in particular 9p21), and for p16 protein expression. DNA was isolated from microdissected sections of normal and tumour cells and analysed for AI/LOH by using six fluorescently labelled microsatellite markers that map to the 9p region. P16 protein expression was examined by immunohistochemistry. At each of the six microsatellite markers the majority of SCC analysed showed AI/LOH. Overall both $\mathrm{AI} / \mathrm{LOH}$ within the CDKN2A locus and absence of p16 protein expression were frequent among the cutaneous SCC analysed, suggesting that p16 inactivation may play a role in cutaneous SCC development. The majority of the SCC analysed also had AI/LOH of the marker within the MTAP gene, and at markers flanking the CDKN2A gene; thus further investigation as to a possible role for these genes in the development of cutaneous SCC is warranted.
\end{abstract}

Keywords: cutaneous $\mathrm{SCC} \bullet \mathrm{AI} / \mathrm{LOH} \bullet \mathrm{p} 16 \bullet \mathrm{p} 15 \bullet \mathrm{MTAP}$

\section{Introduction}

$\mathrm{P} 16^{\mathrm{INK}} 4 \mathrm{~A}$ is a tumour suppressor protein that acts as a CDK 4/6- specific cyclin dependent kinase inhibitor.[1] P16 INK4A competes with Cyclin D for binding to $\mathrm{CDK} 4 / 6$ and thus prevents $\mathrm{Rb}$ from

\footnotetext{
* Correspondence to: Professor Mohamed MABRUK Advanced Medical and Dental Institute, University Sains Malaysia, USM11800, Penang, Malaysia.

Tel.: 006046532728

Fax: 006046532724

E-mail: mmabruk03@yahoo.co.uk
}

being hyperphosphorylated; resulting in $\mathrm{Rb}$ dependent cell cycle arrest in the G1 phase of the cell cycle.[2,3]

The p16 1 INK4A tumour suppressor protein is encoded by the cyclin-dependent kinase inhibitor 2A gene (CDKN2A), which is located on chromosome 9p21.[4, 5] The CDKN2A locus also encodes another tumour suppressor protein known as p19ARF. P16INK4A (P16) and p19ARF have separate promoters and a separate exon 1, but share the same 
exon 2 and exon 3, though the two proteins are translated in different reading frames. P19ARF binds and inhibits Mdm2, thus preventing Mdm2 mediated p53 degradation. $[1,6]$

Alterations of the p16 gene by point mutations, deletion or methylation have been found in a subset of many primary tumours.[7-15]

Enders et al. have reported that murine esophageal SCC cell lines lacking endogenous p16 expression show growth inhibition when exogenous p16 is expressed.[16]

A role for p16 inhibition in the development of cutaneous SCC has been suggested by the findings that mice with targeted disruption of exon 2 and 3 of the $c d k n 2 A$ locus are susceptible to the development of cutaneous SCC after UV irradiation.[17] Also, mutations of the CDKN2A locus, some of which are signature mutations of UV, have been identified in up to $20 \%$ of sporadic cutaneous SCC and in $42 \%$ of cutaneous SCCs from PUVA treated Psoriasis patients.[18-21]

The 9p21 region also contains two other tumour suppressor genes, P15 INK4B (CDKN2B) and Methylthioadenosine phosphorylase (MTAP). P15INK4B acts as an effector of TGF- $\beta$ mediated cell cycle arrest.[22] The p15INK4B protein binds to the cdk4- Cyclin D complex, displacing p27, thus freeing p27 to bind to and inhibit the cdk2- Cyclin E complex, which is required for entry into the $\mathrm{S}$ phase of the cell cycle.[3, 22] Homozygous deletions of the p15 INK4B gene have been found in approximately half of esophageal SCC cell lines and head and neck SCC (HNSCC) examined and also in a subset of ovarian tumours and bladder cancer cell lines [23-26]. Hypermethylation of the $\mathrm{p} 15^{\mathrm{INK}} 4 \mathrm{~B}$ gene has also been found in the majority of HNSCC analysed, as well as in a subset of pulmonary SCC and oral SCC [12, 27-29].

The MTAP gene is a housekeeping gene that plays an important role in the salvage of both adenine and methionine. MTAP protein functions by catalysing the phosphorylation of methylthioadenosine (MTA), which leads to MTA (a by-product of the synthesis of polyamines) being broken down into adenine and methionine [30]. MTA acts as a potent inhibitor of both polyamine aminopropyltransferase and methyltransferases [31-32]. MTAP has been shown to act as a tumour suppressor gene in vitro [32].

An inverse correlation between MTAP protein expression and progression of melanocytic tumours has been observed by Behrmann et al., which sug- gests that inactivation of MTAP may play a role in the development of melanomas.[31] Homozygous deletions of the MTAP gene have been found in just over a third of bladder cancer cell lines, non-small cell lung carcinoma and osteosarcoma.[26, 33-34]

The aim of this study was to examine the integrity of the CDKN2A locus (encoding p16 protein), the p15 INK4B and the MTAP gene regions in twenty-two histologically confirmed cutaneous SCC by analysing the presence of allelic imbalance/loss of heterozygosity $(\mathrm{AI} / \mathrm{LOH})$ at microsatellite markers within and/or flanking the genes of interest. P16 protein expression in these cutaneous SCC tissue samples was also examined.

\section{Materials and methods}

\section{Samples for analysis}

Twenty-two histologically confirmed formalin fixed paraffin-embedded cutaneous invasive squamous cell carcinoma (SCC) were randomly selected from the archives of Beaumont Hospital, Dublin, for analysis.

\section{Stereomicroscopic microdissection and DNA extraction}

Tumour and normal samples were microdissected from preselected areas on Haematoxylin stained sections and DNA isolated from the tumour and normal tissue cells by proteinase $\mathrm{K}$ digestion as described by Butler et al. [35]. For each SCC sample, the corresponding reticular dermal tissue was selected as a constitutional normal control as recommended previously by Zauber et al [36]. One to three $8 \mu \mathrm{m}$ sections were dissected from each SCC sample depending on the size of the tumour and normal reticular dermal tissue.

\section{PCR amplifications}

The microsatellite markers chosen for analysis of the integrity of chromosome 9p21 were D9S916, D9S974, D9S942, D9S1604, D9S1814. The order of the genes of interest on 9p21 is telomere- MTAP- CDKN2A- p15 INK4B - centromere. The D9S916 marker is within intron 4 of the MTAP gene, D9S974 and D9S942 are within the CDKN2A locus. D9S1604 is located between the CDKN2A and p15 INK4B 
Table 1 PCR conditions for amplification of the microsatellite markers

\begin{tabular}{lccccc}
\hline Primer pair & $\begin{array}{c}\text { Initial annealing } \\
\text { temperature }\left({ }^{\circ} \mathrm{C}\right)\end{array}$ & $\begin{array}{c}\text { Final annealing } \\
\text { temperature }\left({ }^{\circ} \mathrm{C}\right)\end{array}$ & Product Size & {$\left[\mathrm{MgCl}_{2}\right]$} & {$[$ Primer $]$} \\
\hline D9S916 & 57 & 55 & $258-285$ base pairs & $1.25 \mathrm{mM}$ & $30 \mathrm{pmol}$ \\
D9S974 & 57 & 55 & $90-135$ base pairs & $1.38 \mathrm{mM}$ & $40 \mathrm{pmol}$ \\
D9S942 & 57 & 55 & $274-279$ base pairs & $1.25 \mathrm{mM}$ & $10 \mathrm{pmol}$ \\
D9S1604 & 57 & 55 & $188-192$ base pairs & $1.25 \mathrm{mM}$ & $20 \mathrm{pmol}$ \\
D9S1814 & 59 & 55 & $274-279$ base pairs & $1.25 \mathrm{mM}$ & $10 \mathrm{pmol}$ \\
D9S171 & 59 & 55 & $157-175$ base pairs & $1.50 \mathrm{mM}$ & $40 \mathrm{pmol}$ \\
\hline
\end{tabular}

genes, and D9S1814 is centromeric to $\mathrm{p} 15^{\mathrm{INK}} 4 \mathrm{~B}$. The D9S171 microsatellite marker at 9p13 was also examined. The DNA sequences of the primers chosen for amplification of these microsatellite markers were obtained from The Genome Database (http://www.gdb.org). In each primer set, the forward primer had a CY-5 label at the 5' end.

PCR amplifications were performed in a final volume of $20 \mu 1$ and consisted of $1 \times$ PCR reaction buffer, $200 \mu \mathrm{M}$ of dNTPs, $1.25-1.5 \mathrm{mM}$ of $\mathrm{MgCl}_{2}$ (Promega, WI, USA), $10-40 \mathrm{pmol}$ of each primer (MWG Biotech, UK), and $2 \mu \mathrm{l}$ of sample DNA digest. The concentration of $\mathrm{MgCl}_{2}$, and of primers used in the PCR reactions varied according to the primers used (Table 1). All PCR protocols were carried out using a hot start in which after an initial denaturation step of $95^{\circ} \mathrm{C}$ for $5 \mathrm{~min}$. the PCR reactions were heated at $80^{\circ} \mathrm{C}$ for 5 min during which time 2 units of Taq DNA polymerase (Promega, WI, USA) was added to each PCR reaction.

A touchdown PCR was then used.[37] This consisted of two cycles of $95^{\circ} \mathrm{C}$ for $1 \mathrm{~min}, 1 \mathrm{~min}$ at an initial annealing temperature (Table 1), and extension at $72^{\circ} \mathrm{C}$ for $1 \mathrm{~min}$. Subsequent steps consisted of two cycles each with annealing temperature reduced by $2^{\circ} \mathrm{C}$ until 32 cycles were done at the final annealing temperature. A final extension step at $72^{\circ} \mathrm{C}$ for 10 min completed the PCR reactions.

PCRs and subsequent fragment analysis of the microsatellite markers were carried out in duplicate for each SCC sample DNA and its corresponding normal tissue DNA.

Following PCR, $4 \mu \mathrm{l}$ of PCR products mixed with agarose loading dye were electrophoresed through $12 \%$ polyacrylamide mini gels. Gels were stained with ethidium bromide $(20 \mathrm{mg} / \mathrm{ml})$ and viewed under UV light to assess the efficiency of amplification. The intensity of the bands seen was used to determine the dilutions necessary for further analysis.

\section{Analysis of allelic imbalance/ loss of heterozygosity $(\mathrm{AI} / \mathrm{LOH})$}

The CY5 labelled PCR products (diluted in distilled water if necessary) were mixed with a CY5.5 labelled DNA size ladder and loading dye, then denatured by heating at $95^{\circ} \mathrm{C}$ for $10 \mathrm{~min}$ and placed on ice.

The samples were then analysed for LOH using the OpenGene Long-Read Tower ${ }^{\mathrm{TM}}$ system DNA Sequencer (Visible Genetics, France). This involved electrophoresis of the samples in a denaturing $6 \%$ polyacrylamide gel heated to $55^{\circ} \mathrm{C}$. Normal and corresponding tumour samples were loaded side by side in the gel. The Sequencer used a laser to excite the fluorescent CY5 label on the PCR products and the CY5.5 label on the internal size markers as they moved through the gel. The Sequencer Fragment analysis software was then able to accurately size the microsatellite alleles in each sample in relation to the internal size markers, and was also able to plot the measured fluorescence in terms of peak area for each microsatellite allele.

A ratio of allele peak areas was calculated by dividing the area of the first allele by the area of the second allele in each of the normal and corresponding tumour DNA samples i.e. T1:T2 and N1:N2 for the tumour samples and their corresponding normals, respectively.

A ratio of ratios between the tumour and normal PCR products was then calculated to give an overall allele ratio, i.e. T1:T2 / N1:N2. In cases where the overall allele ratio calculated by this equation was over 1.00 the inverse was used to give a result between 0.00 and 1.00 [38].

An experimentally established $\mathrm{AI} / \mathrm{LOH}$ allele ratio cut-off point of 0.88 was previously calculated in our laboratory using the microsatellite marker D13S267 and corresponding heterozygote normal samples to 


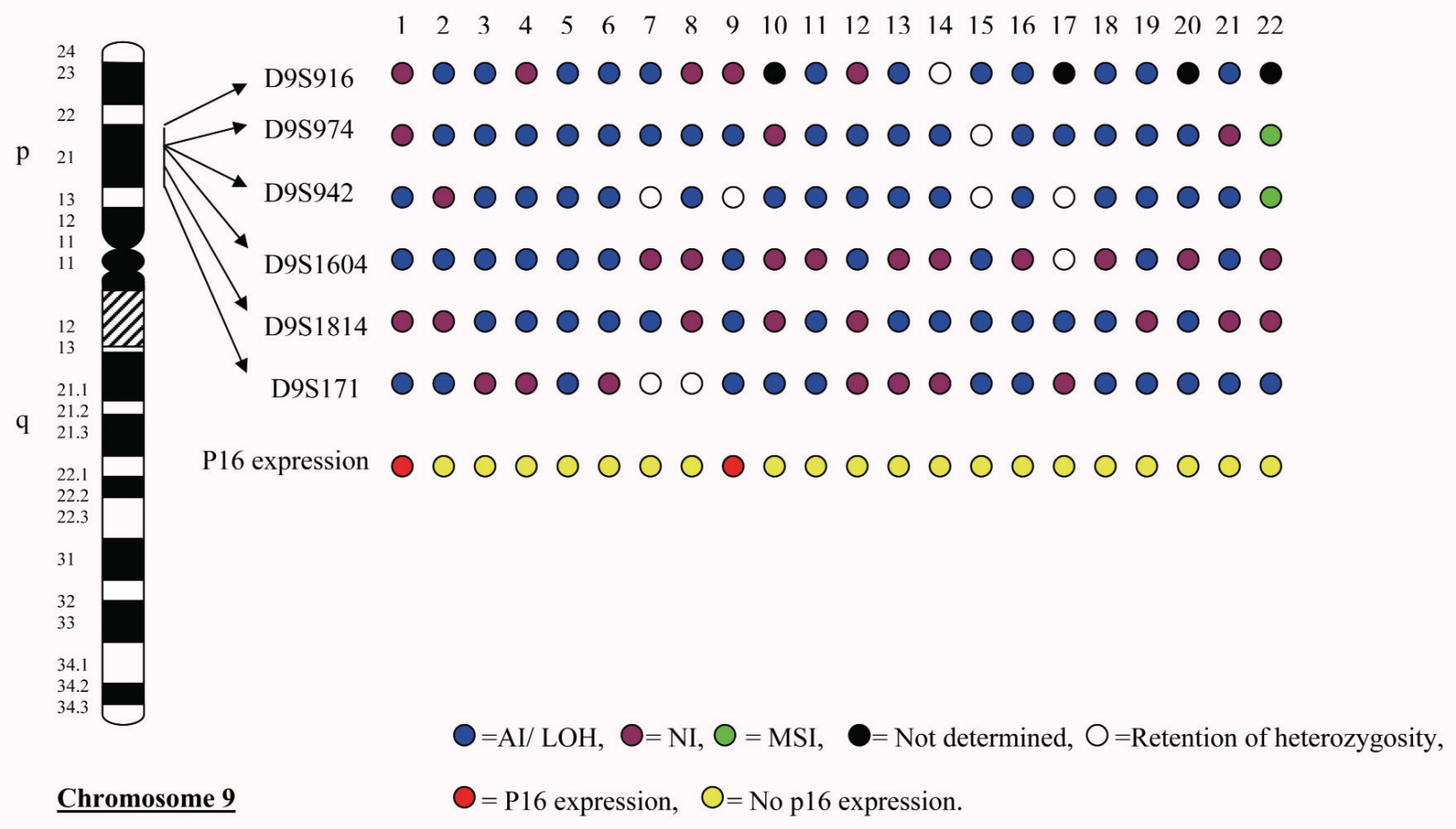

Fig. 1 AI/LOH results at the D9S916, D9S974, D9S942, D9S1604, D9S1814 and D9S171microsatellite markers and $\mathrm{p} 16$ expression for the 22 cutaneous SCC samples.

sixteen of the SCC used in the present study. Two aliquots of DNA from each of the sixteen normal DNA samples were amplified by PCR. Then the pairs of PCR products from each of the sixteen normal DNA samples were loaded side by side in the $6 \%$ polyacylamide gel attached to the Visible Genetics Sequencer in order to mimic the normal/tumour relationship. This was done in duplicate, and the mean allele ratios of the duplicated sixteen paired normal DNA samples was calculated. From these means, the overall mean and the overall standard deviation from the mean was calculated. Assuming a normal distribution it was found that $99.5 \%$ of normal DNA samples (i.e. DNA with retention of heterozygosity) would have allele ratios greater than or equal to 0.89 (i.e. less than or equal to $11 \%$ loss of allele signal in the tumour DNA as compared to the corresponding normal DNA).

\section{Immunohistochemical detection of p16 expression}

The twenty-two cutaneous SCC samples, which were analysed for AI/LOH or instability at the D9S916, D9S974,
D9S942, D9S1604, D9S1814 and D9S171 microsatellite markers were analysed immunohistochemically for the expression of the tumour suppressor protein, p16.

For immunohistochemical detection of the p16 protein, the antibody used was the anti-p16 $6^{\mathrm{INK} 4 \mathrm{a}}(\mathrm{Ab}-7)$ antibody from Neomarkers (Lab Vision UK Ltd., Suffolk, England). A case of cervical intraepithelial neoplasia grade III (CIN III) known to strongly express P16 protein was used as a positive control. Another section of the CIN III to which no p16 antibody was added served as a negative control. Extra sections were taken from two of the cutaneous SCC samples, and these served as additional negative controls by omitting the p16 antibody.

Four $\mu \mathrm{m}$ sections of the formalin fixed paraffin embedded samples were deparaffinized and rehydrated through graded alcohols to water. Endogenous peroxidase activity was blocked by incubating the sections in two changes of $0.9 \%$ hydrogen peroxide for 15 min each change at room temperature. The antigenic sites were unmasked by pressure-cooking the sections in $0.01 \mathrm{M}$ Sodium Citrate solution (pH 6) for 2 min. The Vectastain ${ }^{\circledR}$ Universal ABC kit (Vector Laboratories, USA) was used as described by the manufacturer. Incubation with the p16 antibody was at a dilution of $1 / 100$, for $30 \mathrm{~min}$ at room temperature. Immunostaining was 

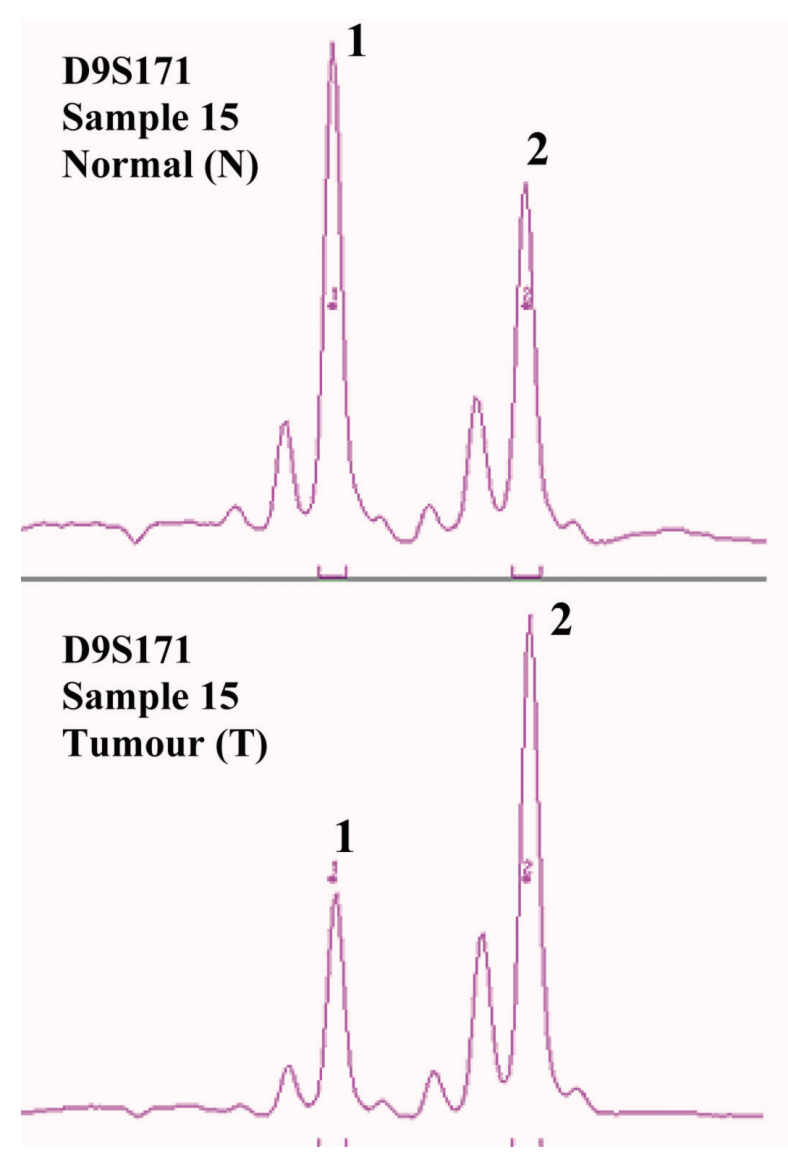

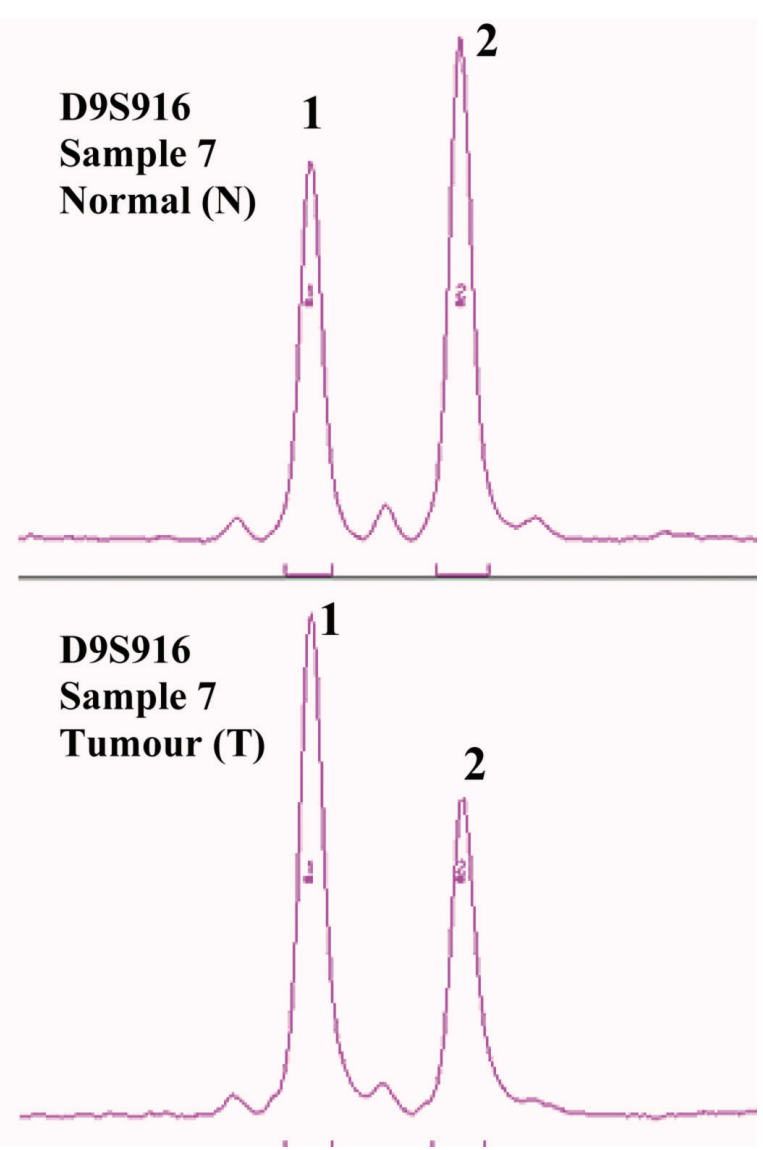

Fig. 2 Electropherograms generated on the Visible Genetics OpenGene Long-ReadTM Tower System. A) Loss of the first allele at D9S171 in SCC sample 15. B) Loss of the second allele at D9S916 in SCC sample 7.

visualized using 3, 3'-diaminobenzidine (DAB) (Zymed, CA, USA) as the substrate chromagen, and sections were counterstained with Harris' Haematoxylin.

The samples were assessed for nuclear staining indicative of p16 expression.

\section{Results}

\section{AI/LOH analysis}

A summary of the $\mathrm{AI} / \mathrm{LOH}$ analysis results obtained for the twenty-two cutaneous SCC samples at the six microsatellite markers is given in Fig. 1.

Of the twenty-two SCC samples analysed for $\mathrm{AI} / \mathrm{LOH}$, the average informative rate per marker was $73 \%$ (range from $55 \%$ to $95 \%$ ). A high rate of $\mathrm{AI} / \mathrm{LOH}$ was seen at all markers. $\mathrm{AI} / \mathrm{LOH}$ was most frequent at the D9S1814 marker $(100 \%$ of informative samples). At the D9S916 locus, $92 \%$ of the infor- mative samples showed AI/LOH (Fig. 2). At the D9S974 and the D9S942 markers, both within the CDKN2A gene, $89 \%$ and $76 \%$ of informative samples showed AI/LOH, respectively. One sample, sample 22, displayed MSI at both the D9S974 and the D9S942 markers (Fig. 3). At the D9S1604 marker, $76 \%$ of the informative samples displayed $\mathrm{AI} / \mathrm{LOH}$ and at the D9S171 marker, $87 \%$ of the informative samples displayed AI/ LOH (Fig. 2).

\section{Immunohistochemical analysis of p16 protein expression in the cutaneous SCC samples}

All of the twenty-two samples of cutaneous SCC were analysed by immunohistochemistry for p16 expression. Only two out of the twenty-two of the cutaneous SCC samples, stained positive for p16 expression. All other cutaneous SCC samples examined were negative for p16 expression. 

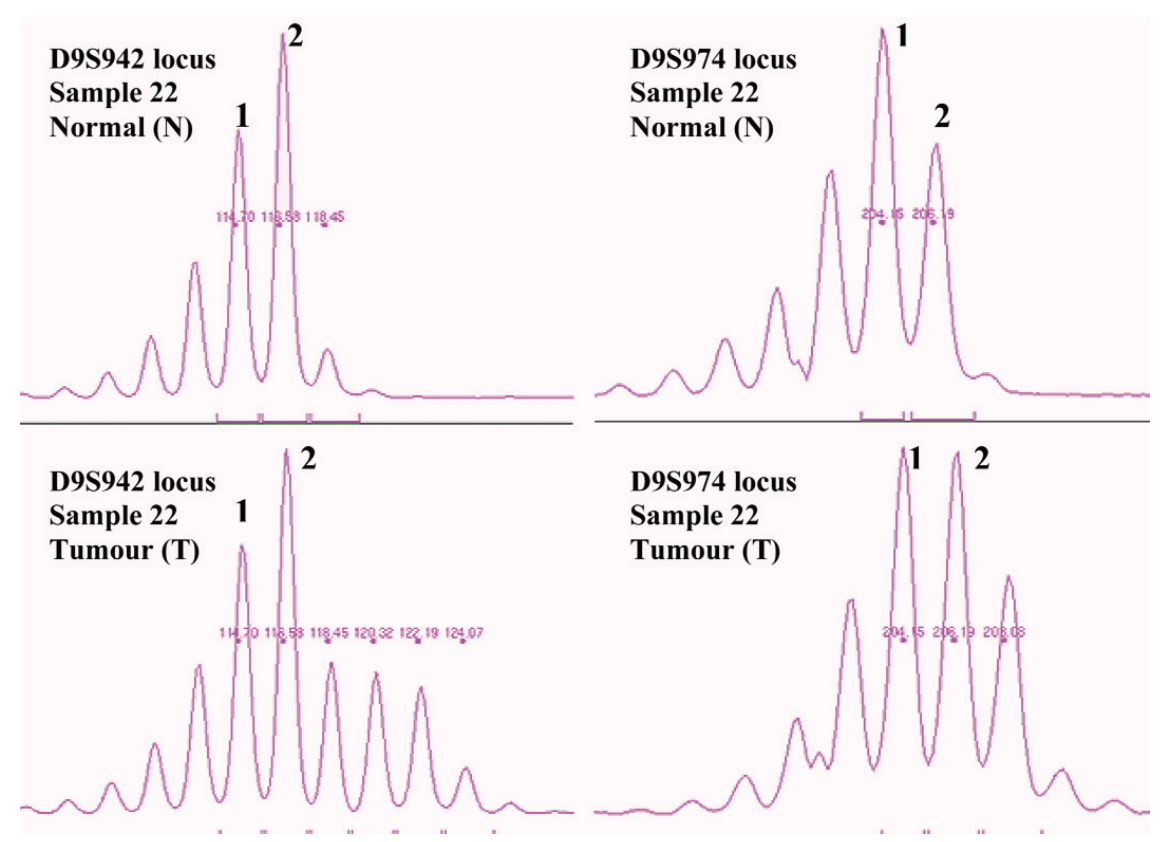

\section{2}
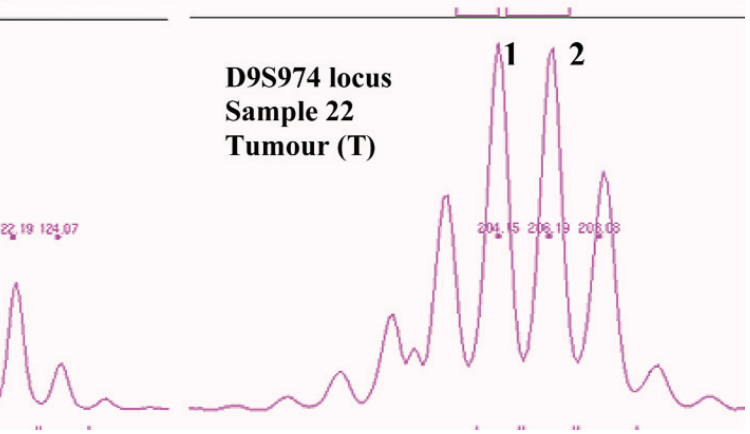

Fig. 3 Microsatellite instability at the D9S942 and the D9S974 loci in cutaneous SCC sample 22. The above electropherograms show the signals that were obtained at the D9S942 and D9S974 microsatellites for the tumour DNA of SCC sample 22 and its corresponding normal DNA. At each loci, the normal DNA displays only two microsatellite alleles, however, in the tumour DNA additional alleles indicative of microsatellite instability can be seen.
Examples of p16 protein expression patterns are illustrated in Fig. 4 (A-D).

The adjacent normal epithelium of twenty-one of the twenty-two SCC samples was negative for p16 expression (sample 1 had no adjacent normal epithelium to evaluate). The normal adjacent reticular dermis of all SCC samples was also negative for $\mathrm{p} 16$ expression.

\section{Correlation between p16 protein expression and $\mathrm{AI} / \mathrm{LOH}$ results}

The relationship between $\mathrm{AI} / \mathrm{LOH}$ at the six microsatellite markers flanking $\mathrm{p} 16$ and expression of the 16 protein in the cutaneous SCC samples is shown in Fig. 1.

In Fig. 1 it can be seen that AI/LOH of the five markers within the 9p21 region and of the D9S171 marker within $9 \mathrm{p} 13$ is frequent. Of particular interest are the two markers closest to the CDKN2A locus. These are the D9S974 marker, which has been mapped within the CDKN2A locus, and the D9S942 marker (centromeric to D9S974), which has been mapped within intron 1 of the CDKN2A locus (NCBI genemap '99). Twenty out of the twenty-two SCC samples were negative for p16 expression. Two of the SCC samples negative for p16 expression showed retention of heterozygosity (ROH) at the D9S942 marker with $\mathrm{AI} / \mathrm{LOH}$ at the
D9S974 marker. Another sample, sample 15, also showed ROH at the D9S942 marker, and also at the D9S974 marker. All other samples that were negative for p16 expression showed AI/LOH at the D9S974 and D9S942 markers (where informative), except for sample 22 which showed MSI at both D9S974 and D9S942.

Only two of the SCC samples were positive for p16 expression (Fig.4 A, B). These were samples 1 and 9. Sample 1 was non-informative at D9S974, but displayed $\mathrm{AI} / \mathrm{LOH}$ at D9S942, where as sample 9 showed $\mathrm{AI} / \mathrm{LOH}$ at D9S974 and $\mathrm{ROH}$ at D9S942.

Overall both $\mathrm{AI} / \mathrm{LOH}$ within the CDKN2A locus and absence of $\mathrm{p} 16$ protein expression were common among the cutaneous SCC samples analysed.

\section{Discussion}

Previous studies on cutaneous SCC have shown that $\mathrm{AI} / \mathrm{LOH}$ is frequent on chromosome $9 \mathrm{p}[20$, 39-40]. The present study focused in particular on the 9p21 region of chromosome 9. This region contains the CDKN2A, p15 and MTAP genes.[4, 41] In the present study, the integrity of these genes in cutaneous SCC was examined by analysing the presence of $\mathrm{AI} / \mathrm{LOH}$ at microsatellite markers located within or flanking the genes of interest. 

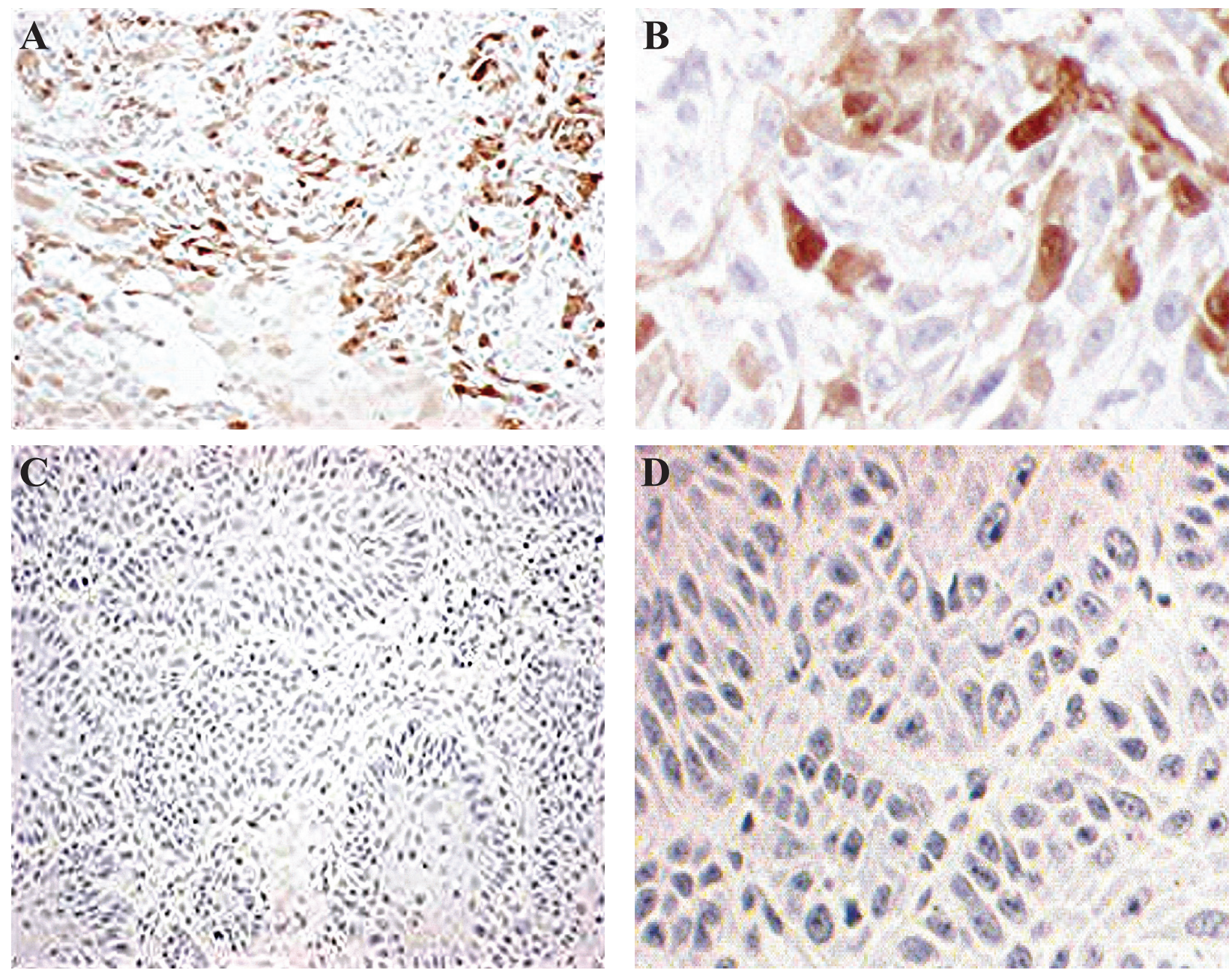

Fig. 4 Immunohistochemical staining of p16 protein expression in cutaneous SCC: A) Immunohistochemical staining of p16 shows strong nuclear expression of p16 protein in the SCC tumour cells (Orginal magnification $\times 200$ ). B) Higher magnification of Fig.4A., showing immunohistochemical staining of p16 protein in the SCC tumour cells (Orginal magnification $\sim \mathrm{x} 400$ ). C) Immunohistochemical staining of p16 shows an absence of p16 protein expression in the squamous cell carcinoma tumour cells of sample 11 (Orginal Magnification x 200). D) Higher magnification of Fig 4C, showing shows an absence of p16 protein expression in the squamous cell carcinoma tumour cells of sample 11 (Orginal Magnification $\sim$ x 400).

The results of the present study show that $\mathrm{AI} / \mathrm{LOH}$ is frequent in the $9 \mathrm{p} 21$ region in invasive cutaneous SCC. This high rate of $\mathrm{AI} / \mathrm{LOH}$ was also seen in the D9S974 and D9S942 microsatellite markers, both of which have been mapped within the CDKN2A gene (NCBI genemap '99), suggesting that inactivation of the CDKN2A gene may play a role in cutaneous SCC. Immunohistochemical analysis of p16 expression in these cutaneous SCC samples found that $\mathrm{p} 16$ was not expressed in $91 \%$ of the samples. Fifteen samples that lacked 16 protein expression showed $\mathrm{AI} / \mathrm{LOH}$ at the D9S942 marker and also showed $\mathrm{AI} / \mathrm{LOH}$ at the D9S974 marker (where informative). As an absence of protein expression requires biallelic inactivation, it appears likely that in these SCC samples $\mathrm{AI} / \mathrm{LOH}$ has inactivated one p16 allele, with the other allele having been inactivated by mutation and/or methylation.

Another three samples that lacked p16 protein expression, showed retention of heterozygosity $(\mathrm{ROH})$ at the D9S942 marker, two of which displayed $\mathrm{AI} / \mathrm{LOH}$ at the D9S974 marker and the other displayed ROH at the D9S974 marker. One SCC that lacked p16 expression showed retention of het- 
erozygosity at both the D9S942 and D9S974 markers. In such fluorescent analysis of $\mathrm{AI} / \mathrm{LOH}$ as employed in this study, apparent ROH may sometimes, though not always, mask homozygous deletions. Therefore further analysis of these samples would be required to rule out if the p16 gene was inactivated as a result of homozygous deletion or mutations and/or methylation. The one remaining SCC sample that did not express p16 protein, was the only sample to display MSI, and showed MSI at both the D9S974 and the D9S942 markers. In this sample it appears likely that MSI has caused inactivating frameshift mutations of the p16 gene, however analysis of the methylation status of the p16 gene in this sample would be required to confirm if MSI was contributing to biallelic inactivation or not.

In normal epithelial tissues P16 expression is not detectable by immunohistochemistry and this is believed to reflect the basal physiological level of p16, however in tumours in which p16 was active, p16 expression detectable by immunohistochemistry would be expected [42-43]. Only two of the examined SCCs were positive for p16 expression, with sample 1 showing particularly intense expression. Such strong expression of p16 in cervical SCC has been associated with inactivation of $\mathrm{Rb}$ as a result of infection with high risk or intermediate risk types of human papilloma viruses (HPV) [44-46]. Sample 1, which showed very strong p16 expression, displayed AI/LOH at the D9S942 marker and was non-informative at the D9S974 marker. Therefore the presence of p16 expression in this sample suggests that although one allele was deleted within intron 1 of the CDKN2A gene, the other allele was wild type and able to compensate for the mutated allele, or that perhaps the deletion was a breakpoint deletion that did not extend far into the CDKN2A locus and both copies of the p16 gene were intact. The overexpression of p16 protein in this sample also suggests that $\mathrm{Rb}$ was inactivated in this SCC sample, though this has yet to be confirmed and whether such $\mathrm{Rb}$ inactivation was due to HPV infection or not also needs to be established.

The only other SCC to express p16 protein reported in the present study was SCC sample number 9 . P16 protein was not overexpressed in sample 9 (as in sample 1), suggesting that $\mathrm{Rb}$ as well as p16 is intact in this sample. Sample 9 showed $\mathrm{AI} / \mathrm{LOH}$ at the D9S974 marker, but retention of heterozygosity at the other marker. As with sample 1, the presence of $\mathrm{p} 16$ expression in this sample rules out biallelic inactivation of the p16 gene, however $\mathrm{AI} / \mathrm{LOH}$ at the D9S974 marker may have been enough to inactivate one of the p16 alleles.

Previous studies have examined p16 expression immunohistochemically in cutaneous SCC with conflicting results.[40, 47-48] Hodges and Smoller have found that $100 \%$ of their cutaneous SCC samples displayed strong p16 expression, whereas Mortier et al. and Brown et al. found that only $10 \%$ and $38 \%$, respectively, of their samples were positive for p16 expression. [40, 47-48] The results of the present study are in agreement with the results found by Mortier et al. and Brown et al., that the majority of cutaneous SCC lack p16 expression. The reason for the conflicting results by Hodges and Smoller is unclear. It is possible that some of the samples that stain positive may be expressing a mutant inactive p16. However, further analysis of their samples at the DNA level would be required to ascertain if that was the case.[40, 47-48]

The results of the present study show that a high proportion of the SCC analysed have AI/LOH within the CDKN2A locus. As the CDKN2A locus also codes for the p19ARF protein, this AI/LOH may be disrupting expression of the p19ARF protein. Although analysis of p19ARF protein expression was not carried out in the present study, Brown et al. have reported an absence of p19ARF expression in $58 \%$ of cutaneous SCC samples analysed, suggesting a role for inactivation of the p19ARF tumour suppressor gene in cutaneous SCC.[47]

In the present study, $\mathrm{AI} / \mathrm{LOH}$ at the D9S916 microsatellite marker located within the MTAP gene was also examined in the cutaneous SCC samples. The number of $\mathrm{SCC}$ with $\mathrm{AI} / \mathrm{LOH}$ at this marker was very high, with 12/13 (92\%) of informative samples showing AI/LOH. This suggests that inactivation of the MTAP gene may be playing a role in cutaneous SCC development.

Two microsatellite markers, the D9S1604 marker (which flanks the p15 gene telomerically) and the D9S1814 marker (which flanks the p15 gene centromerically) were also examined for $\mathrm{AI} / \mathrm{LOH}$ in the cutaneous SCC samples. At the D9S1604 marker 11/12 (92\%) informative samples displayed AI/LOH and at the D9S1814 marker 14/14 (100\%) of informative samples displayed $\mathrm{AI} / \mathrm{LOH}$. This very high rate of $\mathrm{AI} / \mathrm{LOH}$ at the markers flanking the p15 gene suggest that inactivation of the p15 may also have a role to play in cutaneous SCC development. 
$\mathrm{AI} / \mathrm{LOH}$ at the D9S171 microsatellite marker, located within 9p13 was also examined in the cutaneous SCC. Using the technique of silver staining, Saridaki et al. have previously found that $20 \%$ of their analysed cutaneous SCC displayed $\mathrm{AI} / \mathrm{LOH}$ at the D9S171 marker.[20] Mortier et al. and Brown et al., using the more sensitive fluorescent technique reported that $24 \%$ and $29 \%$, respectively, of their cutaneous SCC samples showed $\mathrm{AI} / \mathrm{LOH}$ at D9S171.[40, 47]. In the present study, the incidence of $\mathrm{AI} / \mathrm{LOH}$ at D9S171 was found to be higher, with $59 \%$ of the cutaneous SCC samples displaying $\mathrm{AI} / \mathrm{LOH}$. The difference in $\mathrm{AI} / \mathrm{LOH}$ rates between the present study and the other two fluorescent studies may be due to the use of different cut-off points. Mortier et al. used non-microdissected tissue and an arbitrarily chosen LOH cut-off point of 0.6 and Brown et al. used microdissected tissue and an arbitrarily chosen cut-off point of 0.5 [40, 47]. In the present study microdissected tissue was used and an experimentally determined $\mathrm{AI} / \mathrm{LOH}$ cut-off point of 0.88 was used. Also the difference in $\mathrm{AI} / \mathrm{LOH}$ results between the studies may be as a result of a different ratio of cutaneous SCC from immunocompetent individuals versus immunosuppressed individuals. Rehman et al. have reported that allelic loss was significantly lower in tumours from immunosuppressed individuals than in tumours from immunocompetent individuals, though the reason for this is unknown [49]. In the present study only four of the twenty-two cutaneous SCC samples are from immunosuppressed individuals, whereas SCC from immunosuppressed individuals accounted for $75 \%$ of Brown et al.'s samples. Mortier et al. do not state if their samples are from immunocompetent or immunosuppressed individuals $[40,47]$.

In conclusion, the high rate of $\mathrm{AI} / \mathrm{LOH}$ found within the CDKN2A locus combined with the immunohistochemical results showing an absence of $\mathrm{p} 16$ expression in the majority of cutaneous SCC, suggests that p16 inactivation may play a role in cutaneous SCC development. Conflicting results regarding P16 protein expression in actinic keratosis (a precursor lesion to cutaneous SCC) have been reported [40, 48, 50]. Therefore it is not yet known whether the loss of p16 expression, seen in the cutaneous SCC in the present study, is a late or early event in SCC tumourigenesis.

In addition, the frequent occurrence of $\mathrm{AI} / \mathrm{LOH}$ at the MTAP gene and at markers flanking the
CDKN2B (P15) gene also warrants further investigation as to a possible role for these genes in the development of cutaneous SCC. The high rate of $\mathrm{AI} / \mathrm{LOH}$ seen in the present study at the 9p13 region also warrants further investigation for other genes involved in SCC tumourigenesis.

\section{Acknowledgment}

The authors would like to thank the medical staff of the Dermatology Clinic at Beaumont Hospital for providing samples from patients with skin cancer; we also thank Muna Sabah for technical assistance. We would also like to acknowledge the Irish Cancer Society and the Royal College of Surgeons in Ireland for their financial support.

\section{References}

1. Stott FJ, Bates S, James MC, McConnell BB, Starborg M, Brookes S, Palmero I, Ryan K, Hara E, Vousden KH, Peters G. The alternative product from the human CDKN2A locus, p14 (ARF), participates in a regulatory feedback loop with p53 and MDM2. EMBO J. 1998; 17: 5001-14.

2. Medema RH, Herrera RE, Lam F, Weinberg RA. Growth suppression by $\mathrm{p} 16$ ink4 requires functional retinoblastoma protein. Proc Natl Acad Sci USA. 1995; 92: 6289-93.

3. Sherr C. The INK4a/ARF network in tumour suppression. Nat Reviews; Mol Cell Biol. 2001; 2: 731-7.

4. Kamb A, Gruis NA, Weaver-Feldhaus J, Liu Q, Harshman K, Tavtigian SV, Stockert E, Day RS, Johnson BE, Skolnick MH. A cell cycle regulator potentially involved in genesis of many tumor types. Science 1994; 264: 436-40.

5. Serrano M, Hannon GJ, Beach D. A new regulatory motif in cell cycle control causing specific inhibition of cyclin D/CDK4. Nature 1993; 366: 704-7.

6. Quelle DE, Zindy F, Ashmun RA. Alternative reading frames of the INK4a tumor suppressor gene encode two unrelated proteins capable of inducing cell cycle arrest. Cell 1995; 83: 993-10.

7. MacKie RM, Andrew N, Lanyon WG, Connor JM. CDKN2A germline mutations in UK patients with familial melanoma and multiple primary melanomas. J Invest Dermatol. 1998; 111: 269-72.

8. Reed JA, Loganzo FJr., Shea CR, Walker GJ, Flores JF, Glendening JM, Bogdany JK, Shiel MJ, Haluska FG, Fountain JW. Loss of expression of the p16/cyclin-dependent kinase inhibitor 2 tumor suppressor gene in melanocytic lesions correlates with invasive 
stage of tumor progression. Cancer Res. 1995; 55: 2713-8.

9. Gorgoulis VG, Koutroumbi EN, Kotsinas A, Zacharatos P, Markopoulos C, Giannikos L, Kyriakou V, Voulgaris Z, Gogas I, Kittas C. Alterations of p16-pRb pathway and chromosome locus 9p21-22 in sporadic invasive breast carcinomas. Mol Med. 1998; 4: 807-22.

10. Muzeau F, Flejou JF, Thomas G, Hamelin R. Loss of heterozygosity on chromosome 9 and p16 (MTS1, CDKN2) gene mutations in esophageal cancers. Int $J$ Cancer. 1997; $72: 27-30$.

11. Jares P, Fernandez PL, Nadal A, Cazorla M, Hernandez L, Pinyol M, Hernandez S, Traserra J, Cardesa A, Campo E. p16MTS1/CDK4I mutations and concomitant loss of heterozygosity at 9p21-23 are frequent events in squamous cell carcinoma of the larynx. Oncogene 1997; 15: 1445-53.

12. Viswanathan M, Tsuchida N, Shanmugam G. Promoter hypermethylation profile of tumor-associated genes p16, p15, hMLH1, MGMT and E-cadherin in oral squamous cell carcinoma. Int J Cancer. 2003; 105: 41-6.

13. Yakushiji T, Uzawa $K$, Shibahara T, Noma H, Tanzawa H. Over-expression of DNA methyltransferases and CDKN2A gene methylation status in squamous cell carcinoma of the oral cavity. Int J Oncol. 2003; 22: 1201-7.

14. Sanchez-Cespedes M, Decker PA, Doffek KM, Esteller M, Westra WH, Alawi EA, Herman JG, Demeure MJ, Sidransky D, Ahrendt SA. Increased loss of chromosome 9p21 but not p16 inactivation in primary non-small cell lung cancer from smokers. Cancer Res. 2001; 61: 2092-6.

15. Hashiguchi $\mathbf{Y}$, Tsuda H, Yamamoto K, Inoue T, Ishiko O, Ogita S. Combined analysis of p53 and RB pathways in epithelial ovarian cancer. Hum Pathol. 2001; 32: 988-96.

16. Enders GH, Koh J, Missero C, Rustgi AK, \& Harlow E. P16 inhibition of transformed and primary squamous epithelial cells. Oncogene 1996; 12: 1239-45.

17. Serrano M, Lee H, Chin L, Cordon-Cardo C, Beach D, DePinho RA. Role of the INK4a locus in tumor suppression and cell mortality. Cell 1996; 85: 27-37.

18. Soufir N, Moles JP, Vilmer C, Moch C, Verola, O, Rivet J, Tesniere A, Dubertret L, Basset-Seguin N. P16 UV mutations in human skin epithelial tumors. Oncogene 1999; 18: 5477-81.

19. Kubo Y, Urano Y, Matsumoto K, Ahsa, K, Arase S. Mutations of the INK4a locus in squamous cell carcinomas of human skin. Biochem Biophys Res. Commun. 1997; $232: 38-41$.

20. Saridaki Z, Liloglou T, Zafiropoulos A, Koumantaki E, Zoras O, Spandidos DA. Mutational analysis of CDKN2A genes in patients with squamous cell carcinoma of the skin. Br J Dermatol. 2003; 148: 638-48.

21. Kreimer-Erlacher H, Seidl H, Back B, Cerroni I, Kerl, H, Wolf P. High frequency of Ultraviolet mutations at the INK4a-ARF locus in squamous cell carcinomas from Psoralen-Plus-Ultraviolet-A-Treated Psoriasis Patients. $J$ Invest Dermatol. 2003; 120: 676-82.
22. Hannon GJ, Beach D. p15 (INK4B) is a potential effector of TGF-beta-induced cell cycle arrest. Nature 1994; 371: 257-61.

23. Tanaka H, Shimada Y, Imamura M, Shibagaki I, Ishizaki K. Multiple types of aberrations in the p16 (INK4a) and the p15 (INK4b) genes in 30 esophageal squamous-cell-carcinoma cell lines. Int J Cancer. 1997; 70: $437-42$.

24. Roesler JM, Livingston EH, Srivatsan E hang P, Wang MB. Deletion of P15 (MTS2) in head and neck squamous cell carcinomas. J Surg Res. 1998; 77: 50-4.

25. Ichikawa Y, Yoshida S, Koyama Y, Hirai M, Ishikawa T, Nishida M, Tsunoda H, Kubo T, Miwa M, Uchida K. Inactivation of $\mathrm{p} 16 / \mathrm{CDKN} 2$ and $\mathrm{p} 15 / \mathrm{MTS} 2$ genes in different histological types and clinical stages of primary ovarian tumors. Int J Cancer. 1996; 69: 466-70.

26. Stadler WM, Olopade OI. The $9 \mathrm{p} 21$ region in bladder cancer cell lines: large homozygous deletion inactivate the CDKN2, CDKN2B and MTAP genes. Urol Res. 1996; 24 : 239-44.

27. Wong TS, Man MW, Lam AK, Wei WI, Kwong YL, Yuen AP. The study of p16 and p15 gene methylation in head and neck squamous cell carcinoma and their quantitative evaluation in plasma by real-time PCR. Eur $J$ Cancer. 2003; 39: 1881-7.

28. Furonaka O, Takeshima Y, Awaya H, Ishida H, Kohno N, Inai, K. Aberrant methylation of p14 (ARF), p15 (INK4b) and p16 (INK4a) genes and location of the primary site in pulmonary squamous cell carcinoma. Pathol Int. 2004; 54: 549-55.

29. Shintani S, Nakahara Y, Mihara M, Ueyama, Y, Matsumura T. Inactivation of the p14 (ARF), p15 (INK4B) and p16 (INK4A) genes is a frequent event in human oral squamous cell carcinomas. Oral Oncol. 2001; 37: 498-04.

30. Subhi A, Diegelman P, Porter C, Tang B, Lu Z , Markham M, Kruger W. Methylthioadenosine phosphorylase regulates ornithine decarboxylase by production of downstream metabolites. J Biol Chem. 2003; 278: 49868-73.

31. Behrmann I, Wallner S, Komyod W, Heinrich P, Schuierer M, Buettner R, Bosserhoff A. Characterization of methylthioadenosin phosphorylase (MTAP) expression in malignant melanoma. Am J Pathol. 2003; 163: 683-90.

32. Christopher S, Diegelman P, Porter K, Kruger W. Methylthioadenosine phosphorylase, a gene frequently codeleted with p16 cdkN2a/ARF, acts as a tumor suppressor in a breast cancer cell line. Cancer Res. 2002; 62: 6639-44.

33. Schmid M, Malicki D, Nobori T, Rosenbach M., Campbell K, Carson D, Carrera C. Homozygous deletions of methylthioadenosine phosphorylase (MTAP) are more frequent than p16INK4A (CDKN2) homozygous deletions in primary non-small cell lung cancers (NSCLC). Oncogene 1998; 17: 2669-75.

34. Garcia-Castellano JM, Villanueva A, Healey JH, Beart RW, Van Tornout JM, Jones PA. Methylthioadenosine phosphorylase gene deletions are common in osteosarcoma. Clin Cancer Res. 2002; 8: 782-7. 
35. Butler D, Collins C, Mabruk M, Barry WC, Leader MB, Kay EW. Deletion of the FHIT gene in neoplastic and invasive cervical lesions is related to high-risk HPV infection but is independent of histopathological features. J Pathol. 2000; 192: 502-10.

36. Zauber NP, Sabbath-Solitare M, Marotta SP. Comparison of allelic ratios from paired blood and paraffin embedded normal tissue for use in a polymerase chain reaction to assess loss of heterozygosity. Molec Diagn. 1999; 4: 29-35.

37. Hecker KH, Roux KH. High and low annealing temperatures increase both specificity and yield in touchdown and stepdown PCR. Biotechniques 1996; 20: 478-85.

38. Cawkwell L, Bell SM, Lewis FA, Dixon MF, Taylor GR, Quirke P. Rapid detection of allele loss in colorectal tumours using microsatellites and fluorescent DNA technology. Br J Cancer. 1993; 67: 1262-7.

39. Quinn AG, Campbell C, Healy E, Rees JL . Chromosome 9 allele loss occurs in both basal and squamous cell carcinomas of the skin. J Invest Dermatol. 1994; 102: $300-3$.

40. Mortier L, Marchetti P, Delaporte E, Martin DL, Thomas P, Piette F, Formstecher P, Polakowska R, Danze PM. Progression of actinic keratosis to squamous cell carcinoma of the skin correlates with deletion of the 9 p21 region encoding the p16 (INK4a) tumor suppressor. Cancer Lett. 2002; 176: 205-14.

41. Nobori T, Takabayashi K, Tran P. Genomic cloning of methylthioadenosine phosphorylase: a purine metabolic enzyme deficient in multiple different cancers. Proc Natl Acad Sci USA. 1996; 93: 6203-8.

42. Schraml P, Struckmann K, Bednar R, Fu W, Gasser T, Wilber K, Kononen J, Sauter G, Mihatsch MJ, Moc H. CDKNA2A mutation analysis, protein expression, and deletion mapping of chromosome $9 \mathrm{p}$ in conventional clear-cell renal carcinomas: evidence for a second tumor suppressor gene proximal to CDKN2A. Am J Pathol. 2001; 158: 593-601.

43. Gonzalez-Zulueta M, Bender CM, Yang AS, Nguyen T, Beart RW, Van Tornout JM, Jones PA. Methylation of the 5'CpG island of the $\mathrm{p} 16 / \mathrm{CDKN} 2$ tumour suppressor gene in normal and transformed human tissues correlates with gene silencing. Cancer Res. 1995; 55: 4531-5.

44. Kanao H, Enomoto T, Ueda Y. Correlation between p14(ARF)/p16(INK4A) expression and HPV infection in uterine cervical cancer. Cancer Lett. 2004; 213: 31-7.

45. Klaes R, Friedrich T, Spitkovsky D, Cerroni l, Kerl H, Wolf P. Overexpression of p16(INK4A) as a specific marker for dysplastic and neoplastic epithelial cells of the cervix uteri. Int J Cancer. 2001; 92: 276-84.

46. Sano T, Oyama T, Kashiwabara K. Expression status of p16 protein is associated with human papillomavirus oncogenic potential in cervical and genital lesions. Am J Pathol. 1998; 153: 1741-8.

47. Brown VL, Harwood CA, Crook T. p16INK4a and p14ARF tumor suppressor genes are commonly inactivated in cutaneous squamous cell carcinoma. $J$ Invest Dermatol. 2004; 122: 1284-92.

48. Hodges A, Smoller BR. Immunohistochemical comparison of p16 expression in actinic keratoses and squamous cell carcinomas of the skin. Mod Pathol. 2002; 15: $1121-5$

49. Rehman I, Quinn AG, Takata M. Low frequency of allelic loss in skin tumours from immunosuppressed individuals. Br J Cancer. 1997; 76: 757-9.

50. Salama ME, Mahmood MN, Qureshi HS. p16INK4a expression in actinic keratosis and Bowen's disease. $\mathrm{Br} J$ Dermatol. 2003; 149: 1006-12. 